\title{
The strength retrogression of special class Portland oilwell cement
}

\section{(Regressão de resistência de um cimento Portland classe especial para cimentação de poço de petróleo)}

\author{
U. T. Bezerra', A. E. Martinelli', D. M. A. Melo', M. A. F. Melo ${ }^{2}$, V. G. Oliveira ${ }^{2}$ \\ ${ }^{1}$ Federal Centre of Tech. Education of Paraiba-CEFET-PB, Av. $1^{\circ}$ Maio 720, Jaguaribe, J. Pessoa, PB 58015-430 \\ ${ }^{2}$ Federal University of Rio Grande do Norte - UFRN, Av. Sen. S. Filho 3000, \\ Campus Lagoa Nova, Natal, RN 59078-970 \\ dartarios@yahoo.com.br,aemart@uol.com.br,dmelo@matrix.com.br,dmelo@interjato.com.br,valeska@eq.ufrn.br
}

\begin{abstract}
Temperatures in excess of $110{ }^{\circ} \mathrm{C}$ result in phase transformations of cement, significantly decreasing its compressive strength. This effect is referred to as strength retrogression. It is frequently observed in cement sheaths of heavy oil wells submitted to steam injection. The present study evaluated the mechanical behavior of Special Class Portland Oilwell Cement (SCPOC) slurries containing silica flour to prevent retrogression. A factorial statistical planning was used to assess the effect of the main variables on the mechanical behavior of cement slurries, i.e., mechanical testing temperature (30,100,120, 180 and $\left.230{ }^{\circ} \mathrm{C}\right)$; contents of silica flour replacing cement (0-18 and 36\%) and curing time for rupture (12 h and 7 days). The results revealed that slurries containing $18 \%$ of silica flour tested at $230{ }^{\circ} \mathrm{C}$ depicted an increase in compressive strength up to $30 \%$ after curing for $12 \mathrm{~h}$ and $10 \%$ after curing for 7 days, indicating retrogression. On the other hand, testing slurries containing silica flour at temperatures up to $180{ }^{\circ} \mathrm{C}$ revealed strength increase of just $10 \%$, suggesting the mechanical stability of the SCPOC, which prevents retrogression. Such behavior was probably related to the relatively low content of $\mathrm{C}_{3} \mathrm{~A}$ and low specific area of the material. Therefore, strength retrogression at typical bottom hole temperatures of up to $180^{\circ} \mathrm{C}$ can be controlled by small additions of silica flour, economically contributing to the use of SCPOC cementing.
\end{abstract}

Keywords: characterization, crystal structure, clinker, oil well cement.

Resumo

Temperaturas superiores a $110^{\circ} \mathrm{C}$ provocam mudanças de fase nos cimentos, reduzindo de forma significativa sua resistência à compressão. Isto é observado com frequência em bainhas de cimento em poços de petróleo pesado, que são submetidos a injeção de vapor. O presente estudo avaliou o comportamento mecânico de pastas para cimentação preparadas com um cimento portland Classe especial contendo silica flour para prevenção da regressão de resistência. Um planejamento fatorial foi usado para verificar o efeito das principais variáveis referentes ao comportamento mecânico de pastas de cimento, ou seja, variação da temperatura do ensaio mecânico (30, 100, 120, 180 e $\left.230{ }^{\circ} \mathrm{C}\right)$; concentração de silica flour $(0 \%, 18 \%$ e 36\%) e tempo de cura até a ruptura $(12 \mathrm{~h}$ e 7 dias). Os resultados revelaram que as pastas contendo $18 \%$ de silica flour a $230{ }^{\circ} \mathrm{C}$ provocaram uma redução na resistência à compressão de $30 \%$ após cura de 12 h e 10\% após cura de 7 dias, indicando, portanto, regressão de resistência. Por outro lado, pastas contendo silica flour submetidas a temperaturas superiores a $180{ }^{\circ} \mathrm{C}$ revelaram redução de resistência de apenas $10 \%$, sugerindo que o SCPOC apresenta estabilidade diante de temperaturas elevadas, o que é um indício de prevenção à regressão de resistência. Este comportamento provavelmente deve estar relacionado ao baixo teor de $C_{3} A$ do SCPOC e à sua baixa superfície especifica. Entretanto, a regressão de resistência de anulares de poços submetidos à temperaturas superiores a $180{ }^{\circ} \mathrm{C}$ geralmente é combatida, com adições de silica flour, o que significa dizer que o SCPOC é um material interessante para combater a regressão de resistência em temperaturas abaixo de $180^{\circ} \mathrm{C}$ sem a necessidade da inclusão de silica flour.

Palavras-chave: caracterização, estrutura cristalina, clínquer, cimentação de poço de petróleo.

\section{INTRODUCTION}

The wide range of results obtained with Portland cement test bodies shows the limited knowledge of this commonly used material. This lack of information increases when Portland cement is submitted to high temperatures, at which time phase changes provoke alterations in physical-chemical and mechanical behavior [1-3].

When submitted to temperatures above $110^{\circ} \mathrm{C}$, hydrated
Portland cement suffers a significant loss of resistance to compression. This phenomenon, identified in the 1950s [1], is known as strength retrogression [4]. It is still not well known, despite its being the subject of various studies that discuss its causes and consequences. It was reported for the first time in the petroleum literature as a result of the growing number of deep well completions [1]. Many other studies have been performed since that time $[2,3,5-8]$. A marked characteristic in all these studies is the difficulty 
in scientifically identifying and predicting the sequence of phase conversions Portland cement undergoes, even though many laboratory conditions were under control, a fact that demonstrates the continued difficulty in assessing strength retrogression. To better illustrate this difficulty, consider that studies by Bazănt and Kaplan [9], who investigated the effect of high temperatures on Portland cement, do not even mention strength retrogression, which shows how much more research needs to be done in this area.

The main and most abundant composite responsible for the resistance to compression of Portland cement is known as $\mathrm{C}-\mathrm{S}-\mathrm{H}$, whose structure is partially crystalline, followed by $\mathrm{CH}$, a crystalline structure denominated portlandite [4]. When submitted to high temperatures, C-S-H converts itself into several other phases, modifying the physical, chemical and mechanical properties of Portland cement. To minimize this effect, the oilwell cement industry has added crystalline silica $[1,2]$ in amounts of up to $40 \%$ as a replacement of Portland cement to increase the pozzolanic reaction and reduce the expansion that usually accompanies fissuring of the composite hardened by hydration. The pozzolanic reaction is characterized by the reaction between $\mathrm{CH}$, formed by the conventional hydration process of phases $\mathrm{C}_{3} \mathrm{~S}$ and $\mathrm{C}_{2} \mathrm{~S}$, with water and pozzolan $[4,12]$, as shown in Table I.

Table I - Pozolanic reaction. [Tabela I - A reação pozolânica.]

\begin{tabular}{cc}
\hline Reaction & Velocity of reaction \\
\hline $2 \mathrm{C}_{3} \mathrm{~S}+6 \mathrm{H} \rightarrow \mathrm{C}-\mathrm{S}-\mathrm{H}(61 \%)+\mathrm{CH}$ & Fast $\rightarrow$ hours and days \\
$2 \mathrm{C}_{2} \mathrm{~S}+4 \mathrm{H} \rightarrow \mathrm{C}-\mathrm{S}-\mathrm{H}(82 \%)+\mathrm{CH}$ & Fast $\rightarrow$ days \\
Pozolan $+\mathrm{CH}+\mathrm{H} \rightarrow \mathrm{C}-\mathrm{S}-\mathrm{H}$ & Slow $\rightarrow$ days and months \\
\hline
\end{tabular}

The crystalline structure of $\mathrm{C}-\mathrm{S}-\mathrm{H}$ resembles that of tobermorite gel $\left(\left[\mathrm{Ca}_{5}\left(\mathrm{H}_{2} \mathrm{Si}_{6} \mathrm{O}_{18}\right) 4 \mathrm{H}_{2} \mathrm{O}\right]\right)$. However, these composites cannot be confused, given that their mechanical and physical-chemical properties are distinct. When heated, $\mathrm{C}-\mathrm{S}-\mathrm{H}$ is converted into various other phases. Between $110{ }^{\circ} \mathrm{C}$ and $120{ }^{\circ} \mathrm{C}$ it is converted into the $\alpha$-dicalcium silicate hydrate $\left(\alpha-\mathrm{C}_{2} \mathrm{~S}\right.$ or $\left.\mathrm{Ca}_{2}\left(\mathrm{HSiO}_{4}\right) \mathrm{OH}\right)$, which has a crystalline structure, high specific mass, high permeability and low resistance to compression. Around $202{ }^{\circ} \mathrm{C}, \mathrm{C}-\mathrm{S}-\mathrm{H}$ can also be converted into tricalcium silicate hydrate $\left(\mathrm{C}_{3} \mathrm{~S}\right.$ or $\mathrm{Ca}_{6} \mathrm{Si}_{2} \mathrm{O}_{7}(\mathrm{OH})_{6}$ ), which has similar characteristics to those of $\alpha-C_{2} S$. The increase in temperature provokes the dehydration of Portland cement, with the generation of composites similar to the original ones that were present in the clinker. The addition of crystalline silica, in the form of silica flour or silica sand, modifies the trajectory of this natural conversion process and transforms C-S-H, at $120^{\circ} \mathrm{C}$, into tobermorite, which shows low permeability and high resistance to compression. At the increased temperature, new transformations occur at $150{ }^{\circ} \mathrm{C}$, with the conversion of tobermorite into xonotlite $\left(\mathrm{Ca}_{6} \mathrm{Si}_{6} \mathrm{O}_{17}(\mathrm{OH})_{2}\right)$ and/or gyrolite $\left(\mathrm{Ca}_{8}\left(\mathrm{Si}_{4} \mathrm{O}_{10}\right)_{3}(\mathrm{OH})_{4} \sim 6 \mathrm{H}_{2} \mathrm{O}\right)$, which are phases that exhibit permeability and resistance to compression similar to that of tobermorite. By raising the temperature to $250{ }^{\circ} \mathrm{C}$, gyrolite is converted into truscottite $\left(\mathrm{Ca}_{7}\left(\mathrm{Si}_{4} \mathrm{O}_{10}\right)\left(\mathrm{Si}_{8} \mathrm{O}_{19}\right)(\mathrm{OH})_{4} \mathrm{H}_{2} \mathrm{O}\right)$, which displays greater permeability and lower resistance to compression than that of tobermorite. Other phases may arise, as is the case of pectolite $\left(\mathrm{NaCa}_{2} \mathrm{HSi}_{3} \mathrm{O}_{9}\right)$ and scawtite $\left(\mathrm{Ca}_{7}\left(\mathrm{Si}_{6} \mathrm{O}_{18}\right) \mathrm{CO}_{3} 2 \mathrm{H}_{2} \mathrm{O}\right)$. The portlandite that was not consumed in the pozzolanic reaction is converted into lime and water [9]. It is important to remember that these conversions do not follow a single path; that is, tobermorite is not converted necessarily into xonotlite, gyrolite and truscotite. Some authors report experiences in which truscotite is converted into xonotlite, that is, an inverse process to that which occurs more frequently [3]. Evidently, for this to occur, curing conditions, such as temperature, water vapor pressure and/or hydrostatic pressure, must be different. These authors report that the presence of free $\mathrm{CaO}$ in detriment to silica favors the first formation of xonotlite, whereas the presence of silica in detriment to free lime favors the first formation of truscotite [10].

In the case of Portland cement without the addition of silica, two exothermal changes in important phases can be observed [9]: one at $105{ }^{\circ} \mathrm{C}$, corresponding to the conversion of C-S-H into tobermorite and the other at $550{ }^{\circ} \mathrm{C}$, corresponding to the conversion of portlandite into lime. The conversion of $\mathrm{C}-\mathrm{S}$-H into $\beta$-wollastonite is reported as starting at $105^{\circ} \mathrm{C}$ [9]. The chemical compositions of these composites are not exactly known. Tobermorite, for example, can have aluminum and sodium incorporated into its crystalline network, which exhibits interstitial defects [3]. The important fact is that these phase variations show similar mechanical and permeability behavior. On the other hand, it was also reported that the network of interstitial pores increases as the curing temperature rises, which is an obvious indication that the pastes must always be cured at low temperatures, since the expulsion of excess water from the paste is done

\section{Mole fraction $\mathrm{CaO} /\left(\mathrm{CaO} / \mathrm{SiO}_{2}\right)$ of starting material}

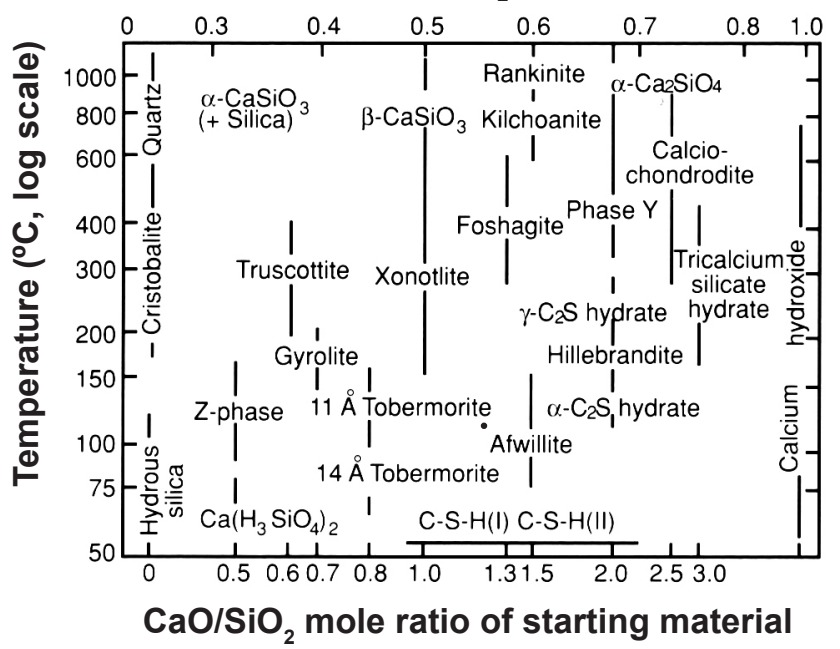

Figure 1: Phase changes in Portland cement submitted to elevated temperatures.

[Figura 1: Mudanças de fase em cimentos Portland submetidos a temperaturas elevadas.] 
in a short time, with the consequent formation of harmful pores [11]. Other secondary composites may be formed, such as foshagite, hillebrandite, jaffeite, afwillite, calciumchrondodite, reyerite (this phase should not be confused with truscotite, as it contains aluminum and alkalis [10]), kilchoanite, rankinite, etc, reported in published studies in at least 22 composites. Fig. 1 may represent the best way of presenting strength retrogression and other phenomena related to phase changes that may occur when hydrated Portland cement is heated [1].

A reduction in strength retrogression can generally be obtained by reducing the $\mathrm{CaO} / \mathrm{SiO}_{2}$ ratio [1] and for this reason silica was added. The addition of silica can be understood by the formation of tobermorite. This phase has 6 $\mathrm{SiO}_{2}$ and $5 \mathrm{Cao}$ molecules, whereas C-S-H usually contains $2 \mathrm{SiO}_{2}$ and $3 \mathrm{CaO}$ molecules. Thus, more $\mathrm{SiO}_{2}$ is always needed (3 times) than Cao (1.67 times) to form tobermorite. Large silica particles react with $\mathrm{C}-\mathrm{S}-\mathrm{H}$ as previously described, forming tobermorite, but smaller particles are converted along with the C-S-H in gyrolite and truscotite without passing through the tobermorite phase. This causes a reduction in phase variations and the preservation of a microstructure with few variations and, therefore more stable from the mechanical point of view. Therefore, the silica added to the Portland cement should always have fine grain size to avoid the formation of tobermorite as the intermediate phase, to be able to reach the gyrolite and truscotite phases. Silica can also be used in the active silica form (silica smoke or volatilized silica) with even tinier particles $(0.10 \mu \mathrm{m}$ and specific surface between $20,000 \mathrm{~m}^{2} / \mathrm{kg}$ and $25,000 \mathrm{~m}^{2} / \mathrm{kg}$ ). This solution may be viable for cements in which lighter pastes are needed with specific masses lower than $1,800 \mathrm{~kg} / \mathrm{m}^{3}$, since the high specific surface of active silica requires a high water/cement factor to allow pumping of the pastes.

With respect to the aluminates celite and ferrite, there is still little knowledge about their behavior at high temperatures [2]. The celites are generally more important, given that they account for $80 \%$ of Portland cement. Furthermore, when some form of silica is added to Portland cement (up to $40 \%$ ), this amount increases to $90 \%$, which determines its behavior at elevated temperatures.

\section{MATERIALS AND METHODS}

The assessment of strength retrogression was performed at the LABCIM (Laboratory of Cements of the Federal University of Rio Grande do Norte). A special Portland class oilwell cement (SPCOC) produced in the northeast of Brazil exclusively for cementing oil wells in this region was used. This cement has been used as a substitute for Portland class $\mathrm{G}$ cement; mean $\mathrm{C} 3 \mathrm{~A}$ content was $5.5 \%$ and mean specific surface was $277.8 \mathrm{~m}^{2} / \mathrm{kg}$.

Silica flour, also produced in the northeast of Brazil, was used as an antiretrogression agent. The residues of a number of granite factories were selected and the fraction corresponding to quartz was isolated and ground until all the material passed through a 200-mesh sieve $(75 \mu \mathrm{m})$.
Statistical assessment, using the factorial planning technique, was adopted with 3 variation factors: curing time (12 h and 7 days); silica flour addition content $(0 \%$, $18 \%$, and $36 \%)$ and assay temperature $(30,100,120$, 180 and $230 \mathrm{C}^{\circ}$ ). For each of the combinations 3 cubic test bodies $(5 \mathrm{~cm}$ edge, according to the specific norm for cementing oil wells [13]).

Although the correlation between curing time and resistance to compression is obvious, this factor was adopted because it has special significance in oil well cementing. It is expected that the pumped pastes have a minimum value of $2.12 \mathrm{MPa}$ for $12 \mathrm{~h}$ of curing. Silica flour content, based on previous exploratory assays, showed an optimal value of between $10 \%$ and $20 \%$ and the temperatures were chosen as a function of phase changes indicated in the literature. A temperature slightly above literature recommendations was always chosen to ensure that the phase change would occur and that resistance to compression would be likely reduced; that is, strength retrogression would take place. Moreover, the maximum temperature adopted $\left(230^{\circ} \mathrm{C}\right)$ owed to the fact that no temperatures above this value have been observed in oil wells in the northeast of Brazil.

The composition of each slurry (combination deriving from factorial planning) was the constant on

To perform the resistance to compression assays of the

Table II - Compositions of slurries.

[Tabela II - Composição das pastas.]

\begin{tabular}{ccccc}
\hline $\begin{array}{c}\text { Addition of } \\
\text { silica flour } \\
{[\%]}\end{array}$ & $\begin{array}{c}\text { SCPOC } \\
{[\mathrm{g}]}\end{array}$ & $\begin{array}{c}\text { Silica } \\
\text { flour } \\
{[\mathrm{g}]}\end{array}$ & $\begin{array}{c}\text { Water } \\
{[\mathrm{g}]}\end{array}$ & FWC \\
\hline 0 & 792.00 & - & 348.48 & 0.44 \\
18 & 709.95 & 127.79 & 312.38 & 0.44 \\
36 & 643.13 & 231.53 & 282.98 & 0.44 \\
\hline
\end{tabular}

Obs.: FWC = factor water/Portland cement

test bodies we used a Shimadzu universal test machine $(10 \mathrm{~N}$ to $100 \mathrm{kN}$ ) with a temperature controlled oven. The machine used Trapezium 2 software, according to oil industry norms [13], and a loading speed of $17.90 \pm 1.80 \mathrm{kN} / \mathrm{min}$.

Up to the moment of rupture, the test bodies remained under curing with total immersion and were removed only $60 \mathrm{~min}$ before the assay. They were then dried with absorbent paper and heated in the oven for the remaining $60 \mathrm{~min}$. This time period was around $45 \mathrm{~min}$; that is, the test bodies were submitted to the temperature predicted in factorial planning for $45 \mathrm{~min}$. At the end of this time the test bodies were ruptured at the predicted temperature, as the test machine allows rupture to occur inside the oven.

\section{RESULTS AND DISCUSSION}

The results obtained are shown in Table III. Each constant value in this table refers to the mean of the 3 assays. This does not mean that the dispersion obtained in 
Table III - Results of compressive strength (MPa).

[Tabela III - Resultados de resistência à compressão (MPa).]

\begin{tabular}{ccccccccccc} 
& \multicolumn{10}{c}{ Curing time (PC) } \\
\cline { 2 - 11 } SF [\%] & $30^{\circ}$ & $100^{\circ}$ & $120^{\circ}$ & $180^{\circ}$ & $230^{\circ}$ & $30^{\circ}$ & $100^{\circ}$ & $120^{\circ}$ & $180^{\circ}$ & $230^{\circ}$ \\
& 11.25 & 10.33 & 7.37 & 8.73 & 9.09 & 24.01 & 23.70 & 24.01 & 23.36 & 23.28 \\
0 & 10.79 & 10.78 & 9.67 & 7.00 & 8.13 & 22.05 & 21.45 & 21.65 & 23.07 & 16.93 \\
& 10.66 & 11.02 & 10.46 & 8.69 & 9.37 & 26.46 & 19.75 & 22.11 & 16.37 & 21.04 \\
\hline \multirow{3}{*}{18} & 10.77 & 11.90 & 11.61 & 12.02 & 11.84 & 25.06 & 23.22 & 24.99 & 22.56 & 23.09 \\
& 11.82 & 12.39 & 11.67 & 11.03 & 11.61 & 26.04 & 21.10 & 23.91 & 24.31 & 19.86 \\
& 11.03 & 11.96 & 12.31 & 11.55 & 11.14 & 27.68 & 23.49 & 23.70 & 22.28 & 23.94 \\
\hline \multirow{2}{*}{36} & 7.20 & 8.05 & 8.34 & 7.56 & 6.54 & 17.39 & 18.28 & 17.48 & 16.45 & 14.23 \\
& 7.32 & 7.81 & 8.00 & 7.90 & 6.03 & 16.45 & 19.32 & 16.97 & 16.86 & 13.80 \\
& 7.98 & 7.73 & 7.65 & 7.83 & 5.72 & 15.96 & 18.33 & 17.39 & 17.02 & 13.65 \\
\hline
\end{tabular}

Table IV - Results of factorial planning (F distribution). [Tabela IV - Resultados do planejamento fatorial (distribuição F).]

\begin{tabular}{cccc}
\hline Effect & F0 calculated & F0 listed & Analysis \\
\hline $\mathrm{PC}[\mathrm{h}$ and d] & $1,602.8$ & 4.0 & $\mathrm{~S}$ \\
$\mathrm{SF}[\%]$ & 139.0 & 3.2 & $\mathrm{~S}$ \\
$\mathrm{~T}\left[{ }^{\circ} \mathrm{C}\right]$ & 8.0 & 2.5 & $\mathrm{~S}$ \\
Interaction PC x SF & 13.1 & 3.2 & $\mathrm{~S}$ \\
Interaction PC x T & 2.2 & 2.5 & $\mathrm{~S}$ \\
Interaction SF x T & 2.1 & 2.1 & $\mathrm{~S}$ \\
\hline
\end{tabular}

S= significant at a $95 \%$ confidence level.

each group of three results was not assessed, given that the systematics of factorial analysis considers this dispersion in their procedures.

Table IV shows the statistical parameters of factorial planning; that is, the parameter F0, calculated from the values obtained, the parameter F0, tabled as a function of the distribution of probabilities $\mathrm{F}$ and the comparison between the two.

The effect of curing time is obviously the most significant $(1,602.8>4.0)$, since it shows the complete development of the hydration process, even with strength retrogression. In sequence, we have the effect of silica flour concentration $(139.0>3.2)$, showing the important role that this material plays in reducing strength retrogression and finally, the effect of rupture temperature $(8.0>2.5)$, demonstrating the critical points at which phase changes in temperature levels occur.

Figs. 2 and 3 show the results in graphic form of the behavior tendencies of the phenomenon.

An interesting feature that can be observed in these two figures is their appearance in the form of a covering with a central summit. This occurs for both the $12 \mathrm{~h}$ and 7 day curing time. This clearly indicates that for all the temperature values adopted in the experiment, there is an optimal silica flour value of around $18 \%$ as a replacement for Portland cement.

For such temperatures and for the $12 \mathrm{~h}$ curing time, resistance to compression increases by between $2.84 \%$ and $41.65 \%$ when $18 \%$ of silica flour is added. For the 7 day curing time, these increases were between $4.48 \%$ and $10.13 \%$; that is, for older ages the effect of silica flour is not as intense as in the first hours, a period corresponding to the time in which the wells produce under precarious curing conditions, causing enhanced performance of the hardened cement sheath. Adding $36 \%$ of silica flour led to a reduction of up to $31.19 \%$ compared to the pastes without addition for the $12 \mathrm{~h}$ curing time and up to $31.98 \%$ for 7 days. This means that there is an optimal range of results corresponding to a number slightly lower that the addition of $18 \%$. Therefore, for additions greater than this value, the compressive strength of the pastes does not increase and the phenomenon of strength retrogression acts more intensely, compromising the physical and mechanical integrity of the sheath. This was observed for all the results; that is, an increase in compressive strength of up to $18 \%$ of silica flour followed by a reduction for higher concentrations. This result is interesting because it shows a optimal feature of SCPOC in strength retrogression, rendering large additions to the pastes unnecessary, as is the case for Portland class G cement, which receives up to $40 \%$ of the antiretrogression agent. In

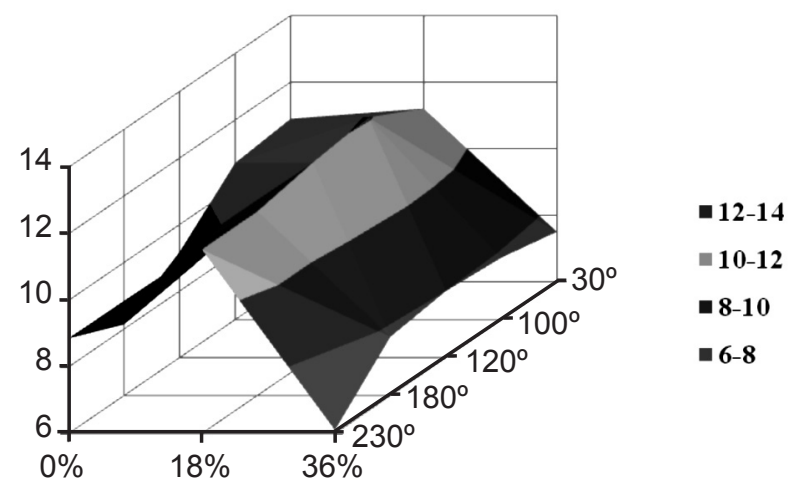

Figure 2: Results to compressive strength after $12 \mathrm{~h}$.

[Figura 2: Resultados de resistência à compressão para $12 \mathrm{~h}$ de cura.] 


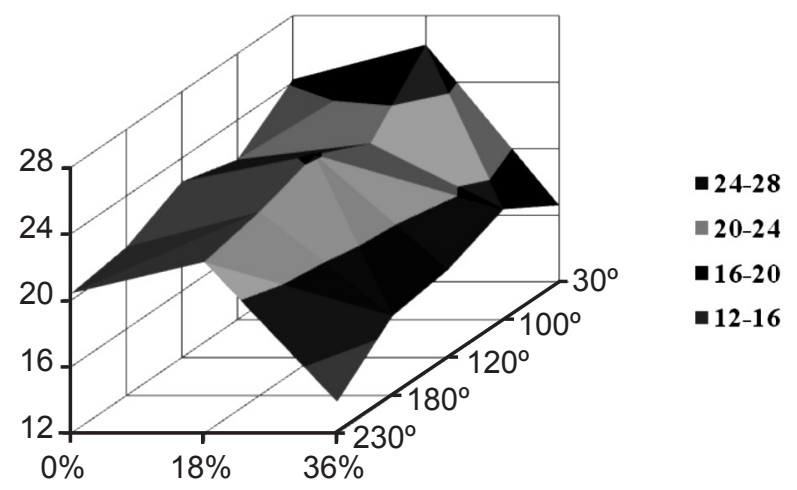

Figure 3: Results to compressive strength after 7 days.

[Figura 3: Resultados de resistência à compressão para 7 dias de cura.]

this case, SCPOC decreases the excessive consumption of the antiretrogression agent, reducing the final cost of the paste. Another advantage involves the rheological properties not discussed in this paper, but which are important at the moment of paste pumping. The addition of silica flour is generally accompanied by an excessive increase in paste viscosity, which requires the introduction of dispersing additives and plastifiers to correct this problem. In the case of SCPOC, as the addition is not very significant (around $18 \%$ ), the additives can be reduced, which decreases the cost of the pumped pastes. On the other hand, the values obtained for compressive strength at increased temperatures show that strength retrogression manifests itself in this cement, albeit slightly, without sharp variations corresponding to the typical phase changes of Portland cement. This demonstrates that SCPOC has characteristics of stability that reduce the damaging effects of strength retrogression, even for pastes that do not receive the addition of silica flour as a replacement for Portland cement.

\section{CONCLUSIONS}

The silica flour used acts as an antiretrogression agent along with SCPOC, which exhibits similar characteristics. The optimal addition of silica flour is a little below $18 \%$. Since the temperatures of wells in the northeast of Brazil are not above $230{ }^{\circ} \mathrm{C}$, the replacement of $18 \%$ of silica flour is adequate for this situation. The study will proceed with the mapping of the phases that are being formed and in which temperatures are occurring by means of X-ray diffraction with the heating mechanism coupled to the diffractometer. Another approach that will be adopted in the LABCIM in a future study will be the adoption of a longer exposure time to assorted temperatures, to determine whether this time influences the final resistance to compression value and the type of phase formed at each temperature level.

\section{REFERENCES}

[1] E. B. Nelson, Well Cementing, Dowell Schlumberger Ed. Serv., Houston, USA (1990).

[2] P. C. Hewlett, Lea's Chemistry of Cement and Concrete, Elsevier/Butterworth-Heinemann, Burlington, USA (2004). [3] H. F. W. Taylor, Cement Chemistry, Thomas Telford, New York, USA (2003).

[4] P. K. Mehta, P. J. M. Monteiro, Concrete: microstructure, properties and materials, McGraw-Hill Professional, New York, USA (2005).

[5] C.-S. Poon, S. Azhar, M. Anson, Y.-L. Wong, Comparison of the strength and durability performance of normal-and high-strength pozzolanic concretes at elevated temperatures, Cement Concrete Res. 31 (2001) 1291-1300.

[6] M. Berra, F. Fabbri, M. Facoetti, A. Noris, M. Pezzuoli, R. Ricciardulli, G. Romano, B. Tarquini, Behaviour of a cementing hydraulic binder under severe geothermal conditions, Geothermics 17 (1988) 785-813.

[7] E. Grabowski, J. E. Gillott, The effect of initial curing temperature on the performance of oilwell cements made with different types of silica, Cement Concrete Res. 19 (1989) 703-714.

[8] B. Vidick, P. Fletcher, M. Michaux, Evolution at early hydration times of the chemical composition of liquid phase of oil-well cement pastes with and without additives. Part II. Cements pastes containing additives, Cement Concrete Res. 19 (1989) 567-578.

[9] P. Z. Bazănt, M. F. Kaplan, Concrete at high temperatures: material properties and mathematical models, Longman Group, Essex, UK (1996).

[10] K. Luke, H. F. W. Taylor, G. L. Kalousek, Some factors affecting formation of truscottite and xonotlite at $300-350{ }^{\circ} \mathrm{C}$, Cement Concrete Res. 11 (1981) 197-203.

[11] Y. Cao, R. J. Detweller, Backscattered electron imaging of cement pastes cured at elevated temperatures, Cement Concrete Res. 25 (1995) 627-638.

[12] R. N. Swamy, N. P. Barbosa, Desenvolvimento de concretos duráveis e resistentes através do uso de cinzas volantes e escória de alto forno moida, SCIENTEC/ LABEME/CT/UFPB, Brazil (1998).

[13] American Petroleum Institute, SPEC A.

(Rec. 18/02/2010, Ac. 13/02/2010) 